Article

\title{
Feature of Adhesins Produced by Human Clinical Isolates of Mycobacterium intracellulare, Mycobacterium intracellulare subsp. chimaera and Closely Related Species
}

\author{
Louise H. Lefrancois ${ }^{1,+}$, Thierry Cochard ${ }^{1}$, Maxime Branger ${ }^{1} \mathbb{D}$, Olivia Peuchant $^{2}$, Cyril Conde $^{1}$, \\ Adeline Pastuszka ${ }^{1,3}$, Camille Locht ${ }^{4}$, Philippe Lanotte ${ }^{1,3, \ddagger}$ and Franck Biet ${ }^{1, *, \ddagger(D)}$ \\ 1 INRAE, Université de Tours, ISP, F-37390 Nouzilly, France; louise.lefrancois.phd@gmail.com (L.H.L.); \\ thierry.cochard@inrae.fr (T.C.); maxime.branger@inrae.fr (M.B.); cyril.conde@inrae.fr (C.C.); \\ adeline.pastuszka@univ-tours.fr (A.P.); philippe.lanotte@univ-tours.fr (P.L.) \\ 2 INRAE, Université de Bordeaux, USC EA 3671 Mycoplasmal and Chlamydial Infections in Humans, \\ Laboratoire de Bactériologie, Centre Hospitalier Universitaire de Bordeaux, F-33000 Bordeaux, France; \\ olivia.peuchant@chu-bordeaux.fr \\ 3 Service Bactériologie-Virologie, Hôpital Bretonneau-CHRU de Tours, F-37044 Tours, France \\ 4 Univ. Lille, CNRS, Inserm, CHU Lille, Institut Pasteur de Lille, U1019-UMR9017—CIIL_Center for \\ Infection and Immunity of Lille, F-59000 Lille, France; camille.locht@pasteur-lille.fr \\ * Correspondence: franck.biet@inrae.fr; Tel.: +33-247-427-869 \\ + Present address: Louise H. Lefrançois, Department of Global Health, Pasteur Institute, F-75015 Paris, France. \\ $\ddagger$ These authors contributed equally to this work.
}

Received: 7 July 2020; Accepted: 29 July 2020; Published: 30 July 2020

check for updates

\begin{abstract}
The Mycobacterium avium complex includes two closely related species, Mycobacterium avium and Mycobacterium intracellulare. They are opportunistic pathogens in humans and responsible for severe disease in a wide variety of animals. Yet, little is known about factors involved in their pathogenicity. Here, we identified, purified and characterized adhesins belonging to the heparin-binding hemagglutinin (HBHA) and laminin-binding protein (LBP) family from M. intracellulare ATCC13950 and examined clinical isolates from patients with different pathologies associated with $M$. intracellulare infection for the presence and conservation of HBHA and LBP. Using a recombinant derivative strain of $M$. intracellulare ATCC13950 producing green fluorescent protein and luciferase, we found that the addition of heparin inhibited mycobacterial adherence to A549 cells, whereas the addition of laminin enhanced adherence. Both HBHA and LBP were purified by heparin-Sepharose chromatography and their methylation profiles were determined by mass spectrometry. Patients with $M$. intracellulare infection mounted strong antibody responses to both proteins. By using PCR and immunoblot analyses, we found that both proteins were highly conserved among all 17 examined clinical $M$. intracellulare isolates from patients with diverse disease manifestations, suggesting a conserved role of these adhesins in $M$. intracellulare virulence in humans and their potential use as a diagnostic tool.
\end{abstract}

Keywords: Mycobacterium intracellulare; NTM; adhesins; HBHA; LBP; MAC infection

\section{Introduction}

Non-tuberculous mycobacteria (NTM) are an increasing cause of opportunistic diseases in humans [1,2]. Among NTM, the Mycobacterium avium complex (MAC) represents a group with a specific distribution of species according to continent and countries [3]. In addition to severe infection in immune-deficient subjects, such as AIDS patients, the incidence of MAC infections has also 
recently increased in patients with chronic pulmonary disease and other underlying conditions $[4,5]$. Due to modifications in mandatory programs of vaccination with bacillus Calmette-Guérin (BCG) in low-incidence countries, an increase in the frequency of adenitis in children was noticed [6] mostly because of MAC infection. MAC is classically divided into Mycobacterium avium and Mycobacterium intracellulare. The $M$. avium species includes four closely related subspecies, $M$. avium subsp. paratuberculosis, the etiologic agent of Johne's disease or paratuberculosis in ruminants [7]. M. avium subsp. avium and M. avium subsp. silvaticum, responsible for avian tuberculosis and infection in wood pigeons, respectively [8] and M. avium subsp. hominissuis, which is usually isolated from pigs but can also be implicated in human infections [9]. Some recently discovered species are very close to $M$. intracellulare and are termed $M$. intracellulare subsp. chimaera intracellulare complex (MCIC) $[10,11]$. M. intracellulare and M. intracellulare subsp. chimaera are associated with infections in humans. M. intracellulare is mainly implicated in pulmonary infections, and M. intracellulare subsp. chimaera [12], was recently associated with fatal infections after cardiac surgery [13]. MAC can be identified by using DNA probes, luminescent systems, DNA sequencing of $r p o B, h s p 65$ and the 16S-23S Intergenic region, or identification of specific insertion sequences [10]. GenoType NTM-DR, a new commercial diagnostic assay, allows differentiation between three MAC species, M. avium, $M$. intracellulare, $M$. intracellulare subsp. chimaera, as well as identification of subspecies within the Mycobacterium abscessus complex [14]. Mass spectrometry has also been recently proposed as a useful tool to identify these NTM at the species level [15].

Several studies have shown that pathogenic mycobacteria use the protein or proteoglycan component of the extracellular matrix (ECM) for adherence and invasion of the host [16]. One of the best characterized mycobacterial adhesins is the heparin-binding hemagglutinin (HBHA), initially identified in Mycobacterium tuberculosis and Mycobacterium bovis bacillus Calmette-Guérin (BCG) [17,18]. However, HBHA-like molecules are also present in many other mycobacteria, both pathogenic and nonpathogenic [19-22]. HBHA is located on the surface of the mycobacteria and mediates binding of the bacilli to epithelial cells and fibroblasts [18] by interacting with sulfated glycoconjugates present on the surfaces of host cells [23]. It also plays a role in the dissemination of M. tuberculosis from the lungs to deeper tissues [24] and has shown promise as a diagnostic target for the detection of latent tuberculosis in humans [25-28].

Laminin and collagen in the lung also promote adherence to ECM-binding mycobacteria, and mycobacterial laminin-binding proteins (LBP) involved in adherence of mycobacteria to host cells have been identified and characterized. LBP was initially described to play a role in the interaction between Mycobacterium leprae and Schwann cells [29-31]. LBP, also referenced to as Lbp/Hlp [32,33], Mdp1, the Mycobacterial DNA-binding protein 1 [30] and hupB the mycobacterial histone-like protein are conserved in mycobacteria, including MAC [32].

In this study, we characterized HBHA and LBP from MCIC species isolated from patients with a variety of disease expression, examined the role of these adhesins in the binding of $M$. intracellulare to lung epithelial cells and their degree of conservation within the MCIC.

\section{Materials and Methods}

\subsection{Bacterial Strains and Growth Conditions}

The reference strain of M. intracellulare ATCC13950 was from the American Type Culture Collection (ATCC), USA. The MAC clinical isolates from AIDS patients and from non-HIV infected patients $(\mathrm{n}=17)$ were collected from inpatients hospitalized at Tours University hospital and Bordeaux University Hospital (France). The protocol was submitted to the local Ethics Committee (protocol authorization no. 2020-062 from the CHU-Tours Ethics Committee in Human Research). No written consent was requested as there was no clinical intervention regarding the healthcare and the study was retrospective. The origin of the samples and clinical context are presented in Figure 1 and Table 1. 

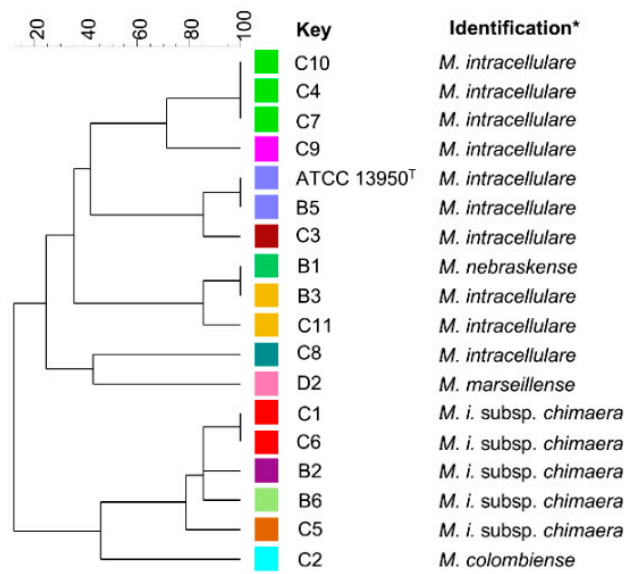

Pathology
Bronchiectasis
Neoplasia
Bronchiectasis
Bronchiectasis
ATCC 13950
Knee septic arthritis
Bronchiectasis
Endobronchic metastatic adenocarcinoma
Pulmonary fibrosis
Bronchiectasis
HIV
Cervical adenitis
COPD
Di<gestive cancer
Endobronchic metastatic adenocarcinoma
Multikystic pulmonary disease + COPD
Pulmonary nodes and cavitary lesion
Acute lymphoblastic leukemia

$\begin{array}{lc}\text { Sample/origin } & \text { ICMV profile number } \\ \text { Expectoration } & 1 \\ \text { Expectoration } & 1 \\ \text { Bronchoalveolar lavage } & 1 \\ \text { Bronchoalveolar lavage } & 8 \\ \text { ATCC } & 3 \\ \text { Knee abscess } & 3 \\ \text { Expectoration } & 13 \\ \text { Expectoration } & 12 \\ \text { bronchial aspiration } & 2 \\ \text { Expectoration } & 2 \\ \text { Bronchoalveolar lavage + blood } & 6 \\ \text { Lymph node biopsy } & 7 \\ \text { Expectoration } & 4 \\ \text { Expectoration } & 4 \\ \text { bronchial aspiration } & 9 \\ \text { bronchial aspiration } & 11 \\ \text { Pulmonary biopsy } & 10 \\ \text { Bronchoalveolar lavage + blood } & 5\end{array}$

Figure 1. Genetic diversity of clinical strains. Clinical isolates were genotyped by Multilocus Variable numbers tandem repeats Analysis (MLVA) based on 7 markers. The MLVA-based polymorphism dendrogram was made with Bionumerics. MLVA profiles are represented by a color. key, strain name; ICMV, M. intracellulare MLVA, * Species were identified by $h s p 65$ sequencing. T, type strain. Chronic obstructive pulmonary disease (COPD).

Table 1. Bacterial strains and plasmid.

\begin{tabular}{|c|c|c|c|c|}
\hline Strains & Identification & Pathology & Specimen/Sample & Reference \\
\hline B1 & M. nebraskense & $\begin{array}{c}\text { Endobronchic metastatic } \\
\text { adenocarcinoma }\end{array}$ & Expectoration & This study \\
\hline B2 & M. i. subsps chimaera & $\begin{array}{c}\text { Endobronchic metastatic } \\
\text { adenocarcinoma }\end{array}$ & bronchial aspiration & This study \\
\hline B3 & M. intracellulare & Pulmonary fibrosis & bronchial aspiration & This study \\
\hline B5 & M. intracellulare & Knee septic arthritis & Knee abscess & This study \\
\hline B6 & M. i. subsps chimaera & $\begin{array}{c}\text { Multikysitic pulmonary } \\
\text { disease + COPD * }\end{array}$ & bronchial aspiration & This study \\
\hline $\mathrm{C} 1$ & M. i. subsps chimaera & COPD & Expectoration & This study \\
\hline $\mathrm{C} 2$ & M. colombiense & $\begin{array}{c}\text { Acute lymphoblastic } \\
\text { leukemia }\end{array}$ & $\begin{array}{l}\text { Bronchoalveolar } \\
\text { lavage }+ \text { blood }\end{array}$ & This study \\
\hline $\mathrm{C} 3$ & M. intracellulare & Bronchiectasis & Expectoration & This study \\
\hline $\mathrm{C} 4$ & M. intracellulare & Neoplasia & Expectoration & This study \\
\hline C5 & M. i. subsps. chimaera & $\begin{array}{l}\text { Pulmonary nodes and } \\
\text { cavitary lesion }\end{array}$ & Pulmonary biopsy & This study \\
\hline C6 & M. $i$. subsps chimaera & Digestive cancer & Expectoration & This study \\
\hline $\mathrm{C} 7$ & M. intracellulare & Bronchiectasis & $\begin{array}{c}\text { Bronchoalveolar } \\
\text { lavage }\end{array}$ & This study \\
\hline $\mathrm{C} 8$ & M. intracellulare & HIV & $\begin{array}{l}\text { Bronchoalveolar } \\
\text { lavage }+ \text { blood }\end{array}$ & This study \\
\hline C9 & M. intracellulare & Bronchiectasis & $\begin{array}{c}\text { Bronchoalveolar } \\
\text { lavage }\end{array}$ & This study \\
\hline $\mathrm{C} 10$ & M. intracellulare & Bronchiectasis & Expectoration & This study \\
\hline C11 & M. intracellulare & Bronchiectasis & Expectoration & This study \\
\hline D2 & M. marseillense & Cervical adenitis & Lymph node biopsy & This study \\
\hline ATCC13950 & M. intracellulare & Type strain & & ATCC \\
\hline Plasmid & & Description & & \\
\hline pSMT3LxEGFP & & Lux, GFP, (Hygromycin) & & \\
\hline
\end{tabular}

M. intracellulare ATCC13950 and human clinical isolates were grown at $37^{\circ} \mathrm{C}$ in Middlebrook 7H9 broth (Difco Laboratories, Detroit, MI, USA), with $0.2 \%$ glycerol and $10 \%$ of ADC (albumin-dextrose-catalase enrichment medium, Becton Dickinson, Le Pont-de-Claix, France). 
Bacteria were harvested at mid-log phase and kept frozen $\left(-80^{\circ} \mathrm{C}\right)$ with $15 \%$ glycerol in aliquots until use.

\subsection{Strain Identification and Genotyping}

2.2.1. Species Identification by GenoType CM and Sequence Analysis of the hsp65 Gene

Identification was performed routinely using GenoType CM (Hain, Life Science). The identification at the species level was performed by $h s p 65$ sequencing. The method for the rapid identification of MAC species was adapted from Talenti et al. [34]. For the PCR, $100 \mu \mathrm{L}$ of culture in a stationary phase was frozen at $-80^{\circ} \mathrm{C}$ for $1 \mathrm{~h}$ then bacteria were heat-killed for $15 \mathrm{~min}$ at $95^{\circ} \mathrm{C}$. PCRs were performed with $5 \mu \mathrm{L}$ of DNA from the thermolysate supernatant added to a final volume of $50 \mu \mathrm{L}$ containing $0.2 \mu \mathrm{L}$ of GoTaq Flexi DNA polymerase ( $5 \mathrm{U} / \mu \mathrm{L}), 2 \mu \mathrm{L}$ dimethyl sulfoxide (DMSO), $2 \mathrm{mM}$ of dATP, $\mathrm{dCTP}, \mathrm{dGTP}$ and dTTP (Promega); $10 \mu \mathrm{L}$ of $5 \times$ PCR buffer supplied by the manufacturer; $1 \mu \mathrm{M}$ of primers $\mathrm{P} 1$ and $\mathrm{P} 2$ (Table 2) and $1.5 \mathrm{mM}$ of $\mathrm{MgCl} 2$. The reactions were carried out using a TC-512 thermal cycler (Techne). PCR conditions were as follows: 1 cycle of 5 min at $94{ }^{\circ} \mathrm{C} ; 30$ cycles of $30 \mathrm{~s}$ at $94{ }^{\circ} \mathrm{C}, 30 \mathrm{~s}$ at $58^{\circ} \mathrm{C}$ and $30 \mathrm{~s}$ at $72{ }^{\circ} \mathrm{C}$; and 1 cycle of $7 \mathrm{~min}$ at $72{ }^{\circ} \mathrm{C}$.

Table 2. List of primers used in this study.

\begin{tabular}{|c|c|c|c|}
\hline Name & Target $^{1}$ Gene $^{1}$ & Sequence & Use \\
\hline P1 & Hsp65-F & ACCAACGATGGTGTGTCCAT & \multirow{4}{*}{$\begin{array}{l}\text { Subspecies } \\
\text { identification }\end{array}$} \\
\hline $\mathrm{P} 2$ & Hsp65-R & CTTGTCGAACCGCATACCCT & \\
\hline P3 & rpoB-F & GGCAAGGTCACCCCGAAGGG & \\
\hline P4 & rpoB-R & AGCGGCTGCTGGGTGATCATC & \\
\hline P5 & Min18-F & GGATTCGGCCGCGCAATTC & \multirow{14}{*}{$\begin{array}{c}\text { MLVA } \\
\text { Typing } 2\end{array}$} \\
\hline P6 & Min18-R & GCCGAACCATTTGGCGAAC & \\
\hline P7 & Min19-F & TAGGGGCAGGTCATCGAAG & \\
\hline P8 & Min19-R & CATGGTTCGCCCTCTACAC & \\
\hline P9 & Min20-F & CGACGCCGATGACGTAAAC & \\
\hline P10 & Min20-R & GCTGAGCTACAGCCTCGAC & \\
\hline P11 & Min22-F & AGCTCGTGACGACGGAAAC & \\
\hline P12 & Min22-R & TCAGGAATGGGTCCGGTTC & \\
\hline P13 & Min31-F & GCTCTATGACGACCTCAAG & \\
\hline $\mathrm{P} 14$ & Min31-R & CGACCGCATCCAGAAACAG & \\
\hline P15 & Min33-F & GGCGTTGAACACGTTGGTG & \\
\hline P16 & $\operatorname{Min} 33-R$ & GTGCAGTTCAACCACGAAC & \\
\hline P17 & MIRU3 new-F & GCAAGCCGGGAACCGGATCG & \\
\hline P18 & MIRU3 new-R & CACCACGGTGGCCTCAAAGC & \\
\hline P19 & HBHA-F & TATACATATGACCATGGCGGAAAACCCGAACATCG & \multirow{6}{*}{$\begin{array}{l}\text { Polymorphism } \\
\text { analysis } \\
\text { and } \\
\text { sequencing }\end{array}$} \\
\hline P20 & HBHA-intra-R & GCCGACCGCGCGGGTCTGCGA & \\
\hline P21 & HBHA intra-F & TATAGAATTCCGCCAAGCTGGTGGGCATCGAGCTGCCG & \\
\hline P22 & HBHA-R & CTACCTACTTCTGGGTGACCTTCTTGGC & \\
\hline $\mathrm{P} 23$ & LBP-F & ATGAATAAGGCAGAGCTC & \\
\hline $\mathrm{P} 24$ & LBP-R & CTACCGGCGGCCGCGACGCG & \\
\hline
\end{tabular}

${ }^{1}$ Abbreviation; F: forward; R: reverse; intra: intragene. ${ }^{2}$ MIN 18 through MIN 33 correspond to Tandem Repeat identified in the study of Dauchy et al. [35].

PCR products (441 bp) were visualized by electrophoresis using 1.5\% agarose gels (agarose electrophoresis grade; Invitrogen), purified using NucleoSpin Extract II (Macherey-Nagel) and sequenced by GenomExpress (Grenoble, France). Sequences were analyzed using the leBIBI-QBPP website https://umr5558-bibiserv.univ-lyon1.fr/lebibi/lebibi.cgi. Phylogeny was performed with a concatenate of SNP using the software Bionumerics@v. 7.6.3 (Applied Maths). 


\subsubsection{MLVA Genotyping}

A Multilocus Variable numbers tandem repeats Analysis (MLVA) profile identification was carried out according to Dauchy et al. [35], using PCR amplification target 7 genetic loci designed from the genome of $M$. intracellulare. The PCR reaction was composed of $1 \mathrm{U}$ GoTaq Flexi DNA polymerase (Promega), $1 \mu \mathrm{M}$ of each primer (Table 2), $1 \mu \mathrm{M}$ dNTP, $5 \mu \mathrm{L} 5 \times$ buffer solution; $1.5 \mathrm{mM} \mathrm{MgCl} 2,1 \mu \mathrm{L}$ DMSO (Sigma); and distilled $\mathrm{H}_{2} \mathrm{O}$ qs $20 \mu \mathrm{L}$. The mixture was added to $5 \mu \mathrm{L}$ of DNA. Amplification conditions were as follows: 1 cycle of $5 \mathrm{~min}$ at $94^{\circ} \mathrm{C} ; 30$ cycles of $30 \mathrm{~s}$ at $94{ }^{\circ} \mathrm{C}, 30 \mathrm{~s}$ at $58^{\circ} \mathrm{C}$ and $30 \mathrm{~s}$ at $72{ }^{\circ} \mathrm{C}$; and 1 cycle of $7 \mathrm{~min}$ at $72{ }^{\circ} \mathrm{C}$. To detect the difference in repeat numbers, the PCR products were analyzed, by electrophoresis in a $1 \%$ agarose gel, by the use of Gel Doc (Bio-Rad, Hercules, CA, USA) and Quantity One 4.2.1 (Bio-Rad, Hercules, CA, USA) software for fragment size calculation. Phylogenetic relationships between the different isolates were analyzed using the software Bionumerics@v. 7.6.3 (Applied Maths, Sint-Martens-Latem, Belgium).

\subsection{PCR DNA Fragment Analysis}

To confirm in silico data from available genomes, detection and size analysis of the $h b h A$ and $l b p$ genes was investigated by PCR as described [20]. The sizes of the PCR products corresponding to $h b h A$ and $l b p$ were determined after the amplification of genomic DNA of all isolates with primers described in Table 2. The fragments were amplified after a denaturation cycle of $5 \mathrm{~min}$ at $94{ }^{\circ} \mathrm{C}$ by using only 23 cycles of $94{ }^{\circ} \mathrm{C}$ for $30 \mathrm{~s}, 61{ }^{\circ} \mathrm{C}$ for $30 \mathrm{~s}$ and $72{ }^{\circ} \mathrm{C}$ for $30 \mathrm{~s}$, followed by a final elongation cycle at $72{ }^{\circ} \mathrm{C}$ for $5 \mathrm{~min}$. The size of the PCR products was analyzed by electrophoresis using $1.5 \%$ agarose gels (agarose electrophoresis grade; Invitrogen, Carlsbad, CA, USA).

\subsection{Construction of Bioluminescent and Fluorescent M. intracelullare Strain}

Green fluorescent protein (GFP)- and luciferase-expressing bacteria were obtained by electroporation of the PSMT3LxEGFP [36] carrying both the GFP- and the bacterial luciferase-coding genes (Lux) into M. intracelullare ATCC 13950. Bacterial cultures $(150 \mathrm{~mL})$ were grown to mid-log phase in Sauton medium and centrifuged at $4500 \times \mathrm{g}$ for $15 \mathrm{~min}$. The pellets were resuspended in $150 \mathrm{~mL}$ of medium supplemented with $10 \%$ glycerol. Cells were centrifuged again, washed three times with $75 \mathrm{~mL}$ of medium supplemented with $10 \%$ glycerol, and resuspended in $5 \mathrm{~mL} 10 \%$ glycerol. Electroporation-ready mycobacterial cells were aliquoted and frozen at $-80{ }^{\circ} \mathrm{C}$ until further use. For transformation, $1 \mu \mathrm{g}$ of pSMT3LxEGFP DNA was mixed with $50 \mu \mathrm{L}$ of cell suspension and pulsed with a Cellject electroporator (Eurogentec, Liège, Belgium) at $2.5 \mathrm{kV}, 800 \Omega$ and $25 \mu \mathrm{F}$. The cells were then harvested in $1.0 \mathrm{~mL}$ Sauton medium and plated onto Middlebrook 7H10 medium supplemented with $\mathrm{ADC}$ and $50 \mu \mathrm{g} \mathrm{ml} \mathrm{m}^{-1}$ of hygromycin. The plates were incubated at $37^{\circ} \mathrm{C}$ and colonies were isolated after 30 to $40 \mathrm{~d}$.

\subsection{Cytoadherence of M. intracelullare to A549 Epithelial Cells}

A549 cells were grown at $37^{\circ} \mathrm{C}$ in an atmosphere of $5 \% \mathrm{CO}_{2}$, in DMEM (Lonza) containing $10 \%$ heated fetal bovine serum (Invitrogen), and supplemented with $2 \mathrm{mM} \mathrm{L-glutamine.} \mathrm{Twenty-four}$ hours before the adhesion assay, $1.5 \times 10^{5}$ cells/well were seeded in a 24 -well plate. The mycobacteria were grown in static conditions in enriched $7 \mathrm{H} 9$ Middlebrook broth supplemented with $0.05 \%$ Tween 80 . At 0.5 of optical density at $600 \mathrm{~nm}$, bacteria were washed once with phosphate-buffered saline (PBS, $10 \mathrm{mM}$ phosphate buffer $\mathrm{pH} 7.2,0.15 \mathrm{M} \mathrm{NaCl}$ ) and resuspended in DMEM. The suspension was vigorously shaken and passed through a $27-G$ needle three times to disrupt bacterial aggregates. The presence of isolated mycobacterial cells was confirmed by microscopic observation. Confluent monolayers were washed twice by PBS before the addition of the appropriate fluorescent-bioluminescent $M$. intracellulare/GFPlux strain (green). The bacterial concentration was adjusted in DMEM and monolayers were infected at a multiplicity of infection of 100 in presence or absence of $80 \mu \mathrm{g} \mathrm{ml} / 1$ heparin or $20 \mu \mathrm{g} \mathrm{mL} / 1$ laminin. After $3 \mathrm{~h}$ of contact at $37^{\circ} \mathrm{C}$ in an atmosphere of 
$5 \% \mathrm{CO}_{2}$, the infected cells were washed three times with PBS and then lysed for $10 \mathrm{~min}$ in $0.1 \%$ Triton X-100 followed by another $10 \mathrm{~min}$ after addition of an equal volume of $0.025 \% \mathrm{SDS}$. The percentage of adhesion was estimated by fluorescence and calculated by luciferase assays, as described below. Cytoadherence of $M$. intracellulare to A549 cells was observed by fluorescence microscopy. The samples were fixed with paraformaldehyde (PFA) and stained with Evans Blue yielding red fluorescence. Images were taken with a $40 \times$ objective.

To quantify the cytoadherence of $M$. intracellulare to A549 cells luminescence was measured using a Berthold Lumat LB 9507 luminometer. As needed, the crude cell lysates were diluted in PBS containing $0.05 \%$ Tween 80 . Aliquots $(100 \mu \mathrm{L})$ of each sample were transferred into a polystyrene test tube (Falcon, PLAM0908) containing $900 \mathrm{~mL}$ dilution buffer and the luciferase activity was measured. Raw data were collected in triplicate and the mean Relative Luminescence Unit (RLU) readings were automatically calculated by the luminometer in-core software. Adhesion assays were performed in triplicate repeated in three independent experiments. The percentage of adhesion was calculated by the following formula: (cell-associated RLU/RLU of the inoculum) $\times 100$. The average and the standard deviation were calculated with the GraphPad Prism software version 6.7.

\subsection{Purification by Heparin-Sepharose Chromatography}

M. intracellulare adhesins were purified by heparin-Sepharose chromatography using a frozen pellet of $M$. intracellulare lysate as described previously [37]. All chromatographic steps were carried out on the Biologic chromatography system (Bio-Rad, Hercules, CA, USA) at room temperature, and the absorbance at $260 \mathrm{~nm}$ was continuously monitored during purification using the HiTrap Heparin HP $(1 \mathrm{~mL}$, GE Healthcare) column $(0.7 \times 2.5 \mathrm{~cm})$ prepacked with heparin-Sepharose. The column was washed with $100 \mathrm{~mL}$ of $20 \mathrm{mM}$ Tris- $\mathrm{HCl}$ (pH 7.2) until the absorbance at $280 \mathrm{~nm}$ was close to 0 . The bound material was eluted by a $0-1 \mathrm{M} \mathrm{NaCl}$ linear gradient in $20 \mathrm{mM}$ Tris- $\mathrm{HCl}$ (pH 7.2), with a flow rate at $0.6 \mathrm{~mL}$ min- 1 and automatically collected in $1 \mathrm{~mL}$ fractions. Whole-cell lysates, flow-through material and eluted fractions were analyzed by sodium dodecyl sulfate-polyacrylamide gel electrophoresis (SDS-PAGE) using 12\% polyacrylamide gels.

\subsection{Identification of the Purified M. intracellulare Proteins by High-Resolution Mass Spectrometry Analysis}

Proteins were digested in-gel with trypsin as previously described [38]. Peptides were analyzed by nanoLC-MS/MS using an Ultimate $₫ 3000$ RSLC coupled to a linear ion trap-orbitrap mass spectrometer (LTQ Velos Orbitrap Mass Spectrometer, Thermo Scientific, Waltham, MA, USA). Protein identifications and post-translational modifications were established as previously described [37].

\subsection{SDS-PAGE and Immunoblotting}

To detect the production of HBHA and LBP mycobacterial whole-cell lysates were resolved by SDS-PAGE, using $12 \%$ running gels and $4 \%$ stacking gels. Proteins were then electro-transferred onto nitrocellulose membranes (Whatman, Germany), followed by a blocking step with $1 \%$ BSA in PBS $/ 0.05 \%$ Tween, washed three times in PBS/0.05\% Tween and then incubated with the monoclonal antibody 3921E4 [39,40]. After three washing steps with PBS/0.05\% Tween, membranes were incubated with goat anti-mouse alkaline phosphatase-conjugated antibody (Caltag, Burlingame, CA, USA) at a 1:2000 dilution. The substrates nitro blue tetrazolium and 5-bromo-4-chloro-3-indolyl phosphate were used to develop the immunoblots.

\subsection{ELISA}

ELISA was performed on 96-well Maxisorp microtiter plates (Nunc, Roskilde, Denmark) coated with native HBHA and LBP purified from $M$. intracellulare in at $0.1 \mathrm{mg} \mathrm{ml} / 1$ in PBS or coated with $50 \mu \mathrm{L}$ of a purified protein derivative from M. avium subsp. paratuberculosis (Johnin PPD [PPDj]) (National Veterinary Institute, Oslo, Norway) at $25 \mathrm{mg} / \mathrm{L}$ in PBS at $4{ }^{\circ} \mathrm{C}$ overnight. Plates were then washed three times with PBS/Tween20 0.05\% (PBS/T) and blocked for $1 \mathrm{~h}$ at $37^{\circ} \mathrm{C}$ with PBS/T containing 
$0.5 \%(\mathrm{w} / \mathrm{v})$ gelatin $(\mathrm{PBS} / \mathrm{T} / \mathrm{G})$. Sera controls were obtained from healthy donors with no context of infection/colonization with MAC. Each serum sample including the sera of the 17 patients infected with MAC, for which the strains were analyzed in this study and sera from 6 healthy controls was diluted at 1:100 in $50 \mu \mathrm{L} \mathrm{PBS} / \mathrm{T} / \mathrm{G}$, and plates were incubated for $2.5 \mathrm{~h}$ at $37^{\circ} \mathrm{C}$. Plates were then washed five times with PBS/T and incubated for $90 \mathrm{~min}$ at $37^{\circ} \mathrm{C}$ with $50 \mathrm{~mL}$ Horseradish peroxidase-conjugated goat antihuman-IgG, AHu/Ig/PO (Nordic Immunological Laboratories, The Netherlands) diluted at 1:500 dilution in PBS/T/G. Plates were washed five times with PBS/T, and $50 \mu \mathrm{L} 2,2^{\prime}$-Azinobis 3-ethylbenzothiazoline-6-sulfonic acid-diammonium salt (ABTS, Thermo Scientific, Waltham, MA, USA) was added according to supplier's recommendations. After $15 \mathrm{~min}$ incubation at $37^{\circ} \mathrm{C}$, the plates were read photometrically at $414 \mathrm{~nm}$.

\subsection{Nucleotide Sequence Accession Numbers}

The $h b h A$ and $l b p$ genes were amplified by PCR using primers P19, P22, P23 and P24 (Sigma) (Table 2) and chromosomal DNA of M. intracellulare 13950 as a template by using Pfu DNA polymerase (Promega). The sequences of $h b h A$ and $l b p$ (Genome Express, Takeley, UK). have been deposited in the GenBank databases under the following accession numbers: KY748358 and KY748359.

\section{Results}

\subsection{Adherence of M. intracellulare to Epithelial Cells is Modulated by Heparin and Laminin}

Previous reports have shown that adherence of mycobacteria to epithelial cells can be modulated by the addition of an extracellular matrix component [18,32]. Using the recombinant $M$. intracellulare strain, we tested whether soluble exogenous heparin or laminin can affect the cytoadherence of M. intracellulare to A549 epithelial cells. As observed qualitatively by fluorescence microscopy in Figure 2A, the recombinant $M$. intracellulare (green) is able to adhere to the A549 epithelial cells, stained with Blue Evans (red). Adherence is inhibited by the addition of heparin and enhanced in the presence of laminin. Quantification of $M$. intracellulare adherence by luciferase assay indicated that this adhesion to epithelial cells was significantly decreased from 50 to $60 \%$ in the presence of exogenous heparin but increased from 35 to $50 \%$ in the presence of exogenous laminin (Figure 2B). The diagram in Figure 2C explains how heparin and laminin can modulate the adhesion of bacteria to cells. The addition of heparin decreases the adhesion of bacteria to cells because it represents targets in competition with the heparin present in cell membranes. Conversely, the addition of laminin will indirectly increase the adhesion of bacteria to the cells via the laminin receptor (Figure 2C).

\subsection{Purification and Characterization of HBHA and LBP from M. intracellulare by Heparin-Sepharose Chromatography}

The modulation of adherence of $M$. intracellulare to epithelial cells by heparin and laminin suggests that M. intracellulare expresses adhesins on its surface, which could be homologs of HBHA and LBP. Thus, to identify and isolate the M. intracellulare protein leading to adherence modulation, we performed heparin-Sepharose chromatography on a soluble extract of $M$. intracellulare, as described to purify HBHA and LBP from other mycobacteria [32,37]. As shown in Figure 3, SDS-PAGE analysis on elution fractions 12 to 18 at ca. $300 \mathrm{mM} \mathrm{NaCl}$ and in fraction 20 to 24 at ca. $600 \mathrm{mM} \mathrm{NaCl}$ contain proteins identified by Mass spectrometry analysis as HBHA and LBP, respectively. Mass spectrometry analysis also confirms the presence of post-translational modifications carried by the HBHA and LBP produced by $M$. intracellulare. As indicated in Table 3 mass spectrometry analysis revealed methylated peptides within the C-terminal lysine-rich repeats domain of HBHA and LBP. 
A
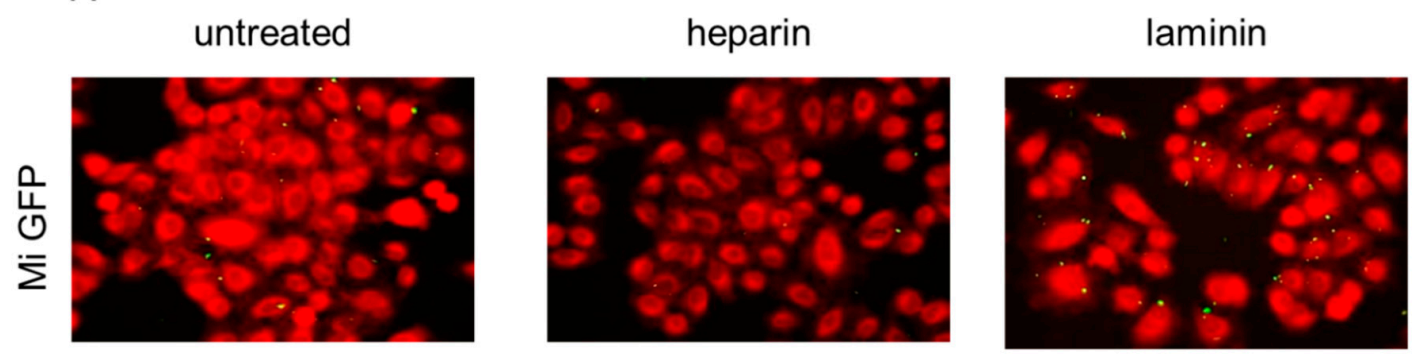

B

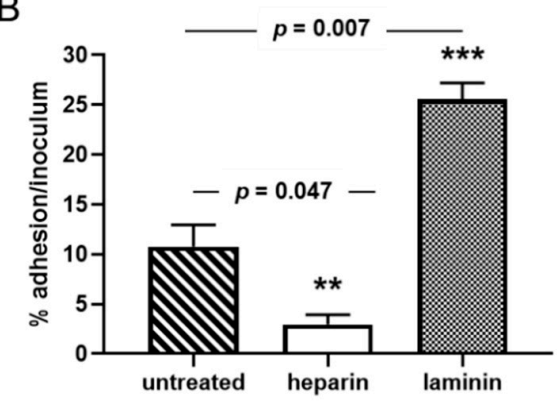

C

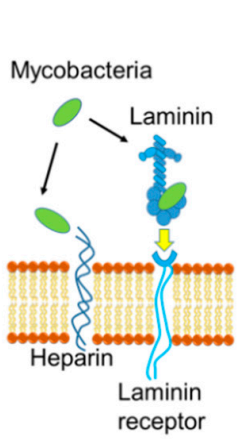

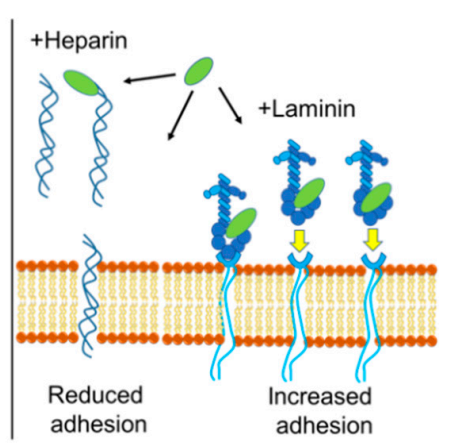

Figure 2. Cytoadherence of M. intracellulare ATCC13950 to A549 epithelial cells inhibited heparin and increased by laminin. A549 cells were infected by Green fluorescent protein (GFP)- and luciferase-producing M. intracellulare ATCC13950 in the presence or absence of heparin or laminin. (A) Fluorescence microscopy analysis of the A549 cells infected by M. intracellulare/GFPlux (green). The samples were fixed with PFA and stained with Evans Blue (red). Images taken with 40× objectives represent the overlay of Evans Blue and GFP signals. (B) Quantification of M. intracellulare /GFPlux adherence by luciferase assays. The percentages of adhesion were calculated by the formula (cell-associated RLU/RLU of the inoculum) $\times 100$. The graph shows the averages of triplicate samples from one representative of three independent experiments. ${ }^{* *} p<0.05 ;{ }^{* * *} p<0.01$. The error bars represent the standard deviation. (C) The diagram gives an illustration of how bacteria bind to cells, either directly on the heparin present on the surface of cells or via laminin which then binds to its cell receptor. In the presence of exogenous heparin or laminin, the adhesion of the bacteria is inhibited or increased.

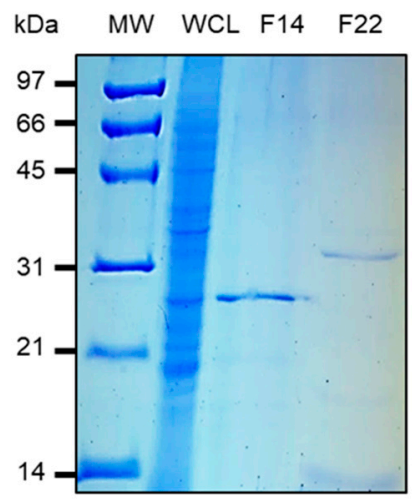

Figure 3. M. intracellulare ATCC 13950 heparin-binding hemagglutinin (HBHA) and laminin-binding protein (LBP) purified by heparin-Sepharose chromatography. A $250 \mathrm{~mL}$ volume of $M$. intracellulare ATCC 13950 culture was centrifuged and the pellet was resuspended in PBS $0.5 \times$. The bacteria were then sonicated and centrifuged. The whole-cell lysate (WCL) was subjected to heparin-Sepharose HiTrap chromatography. SDS-PAGE analysis shows the eluted material in fraction 14 (F14) at ca. $300 \mathrm{mM} \mathrm{NaCl}$ contains M. intracellulare HBHA, as determined by HR-MS/MS whereas the M. intracellulare-LBP was identified in fraction 22 (F22), eluted at ca. $600 \mathrm{mM} \mathrm{NaCl}$. The molecular weights (MW) expressed in $\mathrm{kDa}$ are indicated in the left margin. 
Table 3. Identification of HBHA and LBP by mass spectrometry analysis.

\begin{tabular}{|c|c|c|}
\hline Peptides Identified by HR-MS/MS * & Start-End Position & Peptide Modification \\
\hline \multicolumn{3}{|l|}{ HBHA } \\
\hline${ }^{70}$ LQEDLPEQFTELR $^{82}$ & $70-82$ & \\
\hline${ }^{93}$ AAEGYLEAATSR ${ }^{104}$ & 93-104 & \\
\hline${ }^{105}$ YNELVER $^{111}$ & 105-111 & \\
\hline${ }^{119}{ }^{\text {LRSQTAFEDASAR }}{ }^{131}$ & 119-131 & \\
\hline${ }^{121}$ SQTAFEDASAR ${ }^{131}$ & $121-131$ & \\
\hline${ }^{132}$ AEGYVDQAVELTQEALGTVASQTR ${ }^{155}$ & 132-155 & \\
\hline${ }^{161}$ AAKmeLVGIELPGK ${ }^{172}$ & 161-172 & Methylated \\
\hline${ }^{164}$ LVGIELPGKTEATAKme ${ }^{178}$ & $164-178$ & Methylated \\
\hline \multicolumn{3}{|l|}{ LBP } \\
\hline${ }^{9}$ AELIDVLTQK $^{18}$ & $9-18$ & \\
\hline${ }^{25}$ QATAAVENVVDTIVR ${ }^{39}$ & 25-39 & \\
\hline${ }^{40}$ AVHKGDSVTITGFGVFEQR ${ }^{58}$ & $40-58$ & \\
\hline${ }^{44}$ GDSVTITGFGVFEQR ${ }^{58}$ & $44-58$ & \\
\hline${ }^{76}$ VKPTSVPAFRPGAQFK $^{91}$ & $76-91$ & \\
\hline${ }^{92}$ AVVSGAQRLPSDGPAVK ${ }^{108}$ & $92-108$ & \\
\hline${ }^{92}$ AVVSGAQRLPSDGPAVKmeR ${ }^{109}$ & 92-109 & Methylated \\
\hline
\end{tabular}

3.3. Conservation of HBHA and LBP within the Panel of Clinical M. intracellulare Isolates and Closely Related Species

All clinical isolates used in this study were identified by GenoType Mycobacterium CM (HAin Lifescience) as M. intracellulare, but we observed high genetic diversity of clinical isolates when subjected to MLVA genotyping (Figure 1). Using SNP analyses on the $h s p 65$ gene sequence we found that nine isolates belong to the species intracellulare. However, five isolates were reclassified to the M. intracellulare subsps. chimaera, one to species marseillense, one to species colombiense and one to species nebraskense (Figure 4).

Previous studies on HBHA and LBP have shown that within the MAC complex the structure and function of these adhesins can vary according to the species and even within the same subspecies, as in M. avium subsp. paratuberculosis [20]. This variability was mostly carried by the C-terminal parts of HBHA and LBP, with a different number of lysine residues that lead to variable C-terminal domain lengths and directly impact the binding affinity to heparin $[20,23]$. We thus investigated by PCR the potential of polymorphisms in the $h b h A$ and $l b p$ genes of these two adhesins. As Figure 5 illustrates, the sizes of the $3^{\prime}$ region of the $h b h A$ and $l b p$ genes, corresponding to the portion encoding the heparin-binding protein domains, exhibited the same size for all clinical isolates.

To investigate the expression of $h b h A$ adhesin and $l b p$ for each clinical isolate, we used a monoclonal antibody able to recognize both HBHA and LBP in immunoblot analyses and found that all the isolates produced the two adhesins at a comparable level and of with the same apparent size (Figure 6). 
A

Locus GroEL hsp65

1 ATGGCCAAGA CAATTGCGTA TGACGAAGAg GCCCGCCGTG GCCTCGAGCG GGGGCTCAAC 61 GCCCTCGCCG ACGCGGTAAA GGTGACGTTG GGCCCCAAGG GTCGCAACGT CGTCCTGGAG 121 AAGAAGTGGG GTGCCCCCAC GATCACCAAC GATGGTGTGT CCATCGCCAA GGAGATCGAG 181 CTGGAGGACC CGTACGAGAA GATCGGCGCC GAGCTGGTCA AGGAAGTCGC CAAGAAGACC 241 GACGACGT CCGGTGACG CACGACGACG GCCACGGTGC TGGoTCAGGC GTTGTCCGC

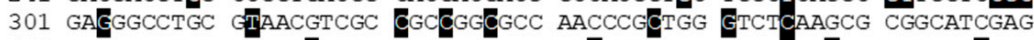
361 AAGGCCGTCG AGAAG GTCAC CGAGACCCTG CTCAAGTCGG CCAAGGAGGT CGAGACCAAG 421 GACCAGATCG OTGCCACCGC GGCGATITCG GCGGGCGACC AGTCGATCGG TGACCTCATC 481 GCCGAGGCGA TGGACAAGGT CGGCAACGAG GGCGTCATCA CCGTCGAGGA GTCCAACACC 541 TTCGGCCTGC AGCTCGAGCT CACCGAGGGC ATGCGGTTCG ACAAGGGCTA CATCTCGGGC 601 TACTTCGTCA CCGACGCCGA GCGTCAGGAA GCGGTCCTCG AGGACCCCTT CATCCTGCTG 661 GTCAGCTCCA AGGTGTCGAC GGTCAAGGAC CTGCTGCCGC TGCTGGAGAA GGTCATCCAG 721 GCCGGCAAGC CGCTGCTGAT CATCGCCGAG GACGTCGAGG GTGAGGCTCT GAGCACCCTG 781 GTCGTCAACA AGATCCGCGG CACCTTCAAG TCGGTGGCCG TCAAGGCCCC CGGCTTCGGT 841 GACCGCCGCA AGGCGATGCT GCAGGACATG GCCATCCTCA CCGGTGGTCA GGTCATCAGC 901 GAAGAGGTCG GCCTGTCGCT CGAGAGCGCC GATGTCGCCC TGCTGGGTAA GGCCCGCAAG 961 GTCGTCGTCA CCAAGGACGA GACCACCATC GTCGAGGGCG CCGGTGACTC GGACGCCATC 1021 GCCGGCCGGG TGGCCCAGAT CCGCAGCGAG ATCGAGAACA GCGACTCCGA CTACGACCGC 1081 GAGAAGCTGC AGGAGCGCCT GGCCAAGCTG GCCGGCGGTG TTGCGGTGAT CAAGGCCGGG 1141 GCCGCGACCG AGGTCGAGCT CAAGGAGCGC AAGCACCGCA TCGAGGACGC GGTGCGCAAC 1201 GCCAAGGCGG CCGTGGAGGA GGGCATCGTC GCCGGTGGTG GCGTGGCCCT GCTGCACGCC 1261 ACCCCGTCGC TGGACGAGCT GAAGCTCACC GGTGACGAGG CGACCGGCGC CAACATCGTC 1321 CGCGTCGCGC TCGAGGCTCC GCTGAAGCAG ATCGCCTTCA ACGGTGGTCT GGAGCCCGGC 1381 GTGGTGGCCG AGAAGGTCCG CAACTCGCCC GCCGGTACCG GCCTGAACGC CGCCACCGGT 1441 GAGTACGAGG ACCTGCTCAA GGCCGGTGTC GCCGACCCGG TGAAGGTGAC CCGTTCGGCG 1501 CTGCAGAACG CCGCGTCGAT CGCGGGCCTG TTCCTGACGA CCGAGGCCGT CGTCGCTGAC 1561 AAGCCGGAGA AGGCCGCCGC TCCCGTCGGC GACCCGACCG GTGGCATGGG CGGCATGGAC 1621 TTСТАA

\section{B Phylogeny based on $h s p 65$ SNP concatenat}

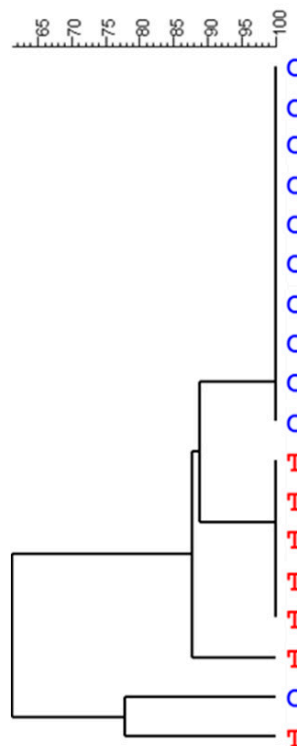

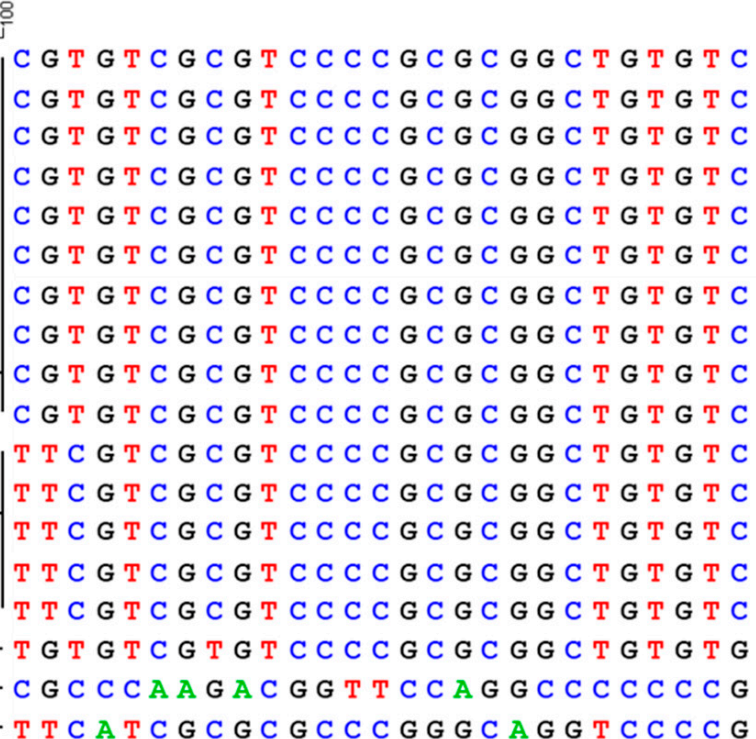

\begin{tabular}{ll} 
Key & \multicolumn{1}{c}{ Identification } \\
ATCC 13950 & M. intracellulare \\
B3 & M. intracellulare \\
B5 & M. intracellulare \\
C10 & M. intracellulare \\
C11 & M. intracellulare \\
C3 & M. intracellulare \\
C4 & M. intracellulare \\
C7 & M. intracellulare \\
C8 & M. intracellulare \\
C9 & M. intracellulare \\
C6 & M. i. subsp chimaera \\
B2 & M. i. subsp. chimaera \\
B6 & M. i. subsp.chimaera \\
C1 & M. i. subsp.chimaera \\
C5 & M. i. subsp. chimaera \\
D2 & M. marseillense \\
B1 & M. nebraskense \\
C2 & M. colombiense \\
\hline
\end{tabular}

Figure 4. Identification of clinical isolates at the species level by $h s p 65$ sequence analysis. (A) The $h s p 65$ sequences are indicated in black characters in the groEL locus (blue characters). All SNPs detected in hsp65 of the 17 clinical isolates are indicated by white letters on the black background. (B) Alignment of the SNP concatenates detected in $h s p 65$ associated with the mycobacterial species identified in the BIBI-QBPP database and SNP-based phylogeny carried out with the Bionumeric software. 
hbhA gene Mi ATCC 13950

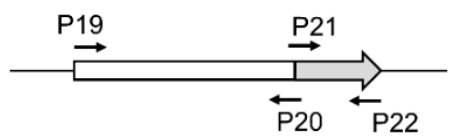

Ibp gene Mi ATCC 13950

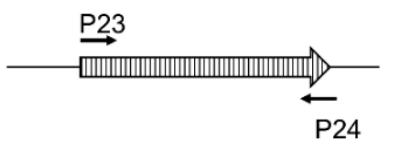

A PCR product (P19-P20)

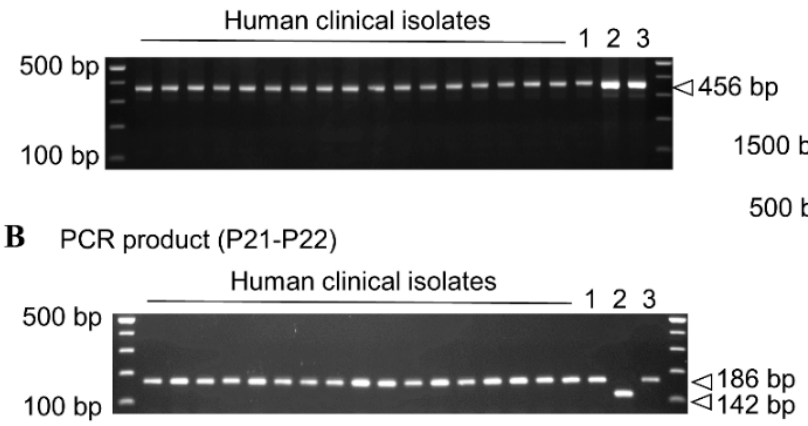

C PCR product (P23-P24)

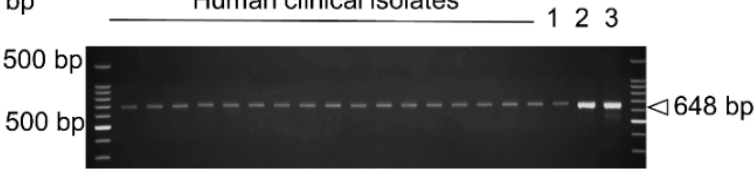

Figure 5. Conservation of the $h b h A$ and $l b p$ genes in human clinical isolates. PCR amplicons of the DNA coding for the N-terminal (A) and the C-terminal domains (B) of $h b h A$, and (C) of $l b p$ obtained by using genomic DNA of M. intracellulare ATCC 13950 and lysates of 17 human isolates, as well as genomic DNA from M. avium subsp. paratuberculosis and M. avium subsp. avium indicated by 1,2 and 3 , respectively. The arrows in the diagram at the top indicate the positions and directions of primers. Positions on a 100-bp ladder (Promega) (A,C) and a low-molecular-weight DNA ladder (New England BioLabs) (B), are indicated in the left margins. The sizes of the PCR products are indicated in the right margins.

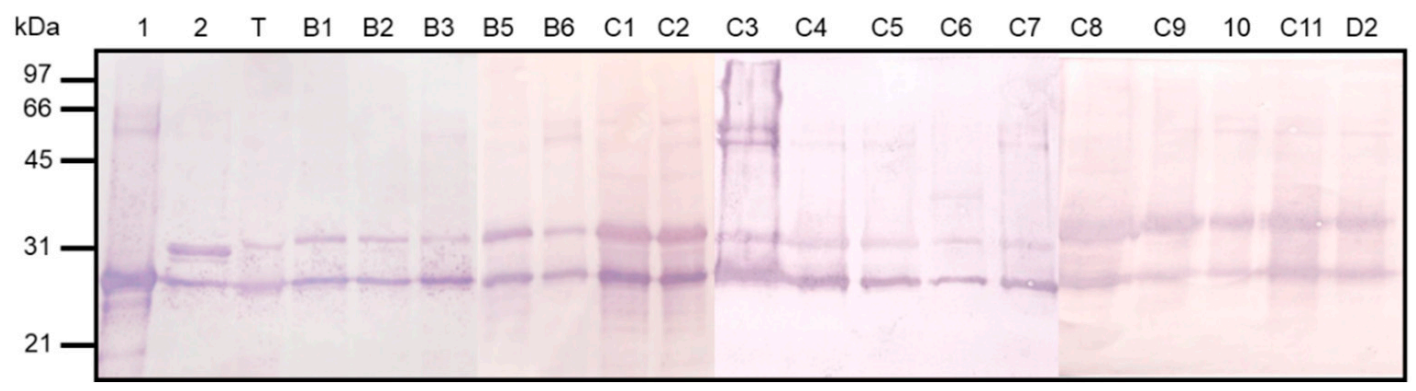

Figure 6. Detection of HBHA and LBP from clinical isolates by immunoblot analysis. HBHA and LBP purified from M. intracellulare ATCC13950 (Lanes 1 and 2, respectively); whole-cell lysate of type strain M intracellulare ATCC13950 used as control (lane T); whole-cell lysates of human clinical isolates (lanes B1 to D2). The immunoblots were probed with monoclonal antibody 3921E4. Sizes of molecular weight markers $(\mathrm{kDa})$ are indicated in the left margin.

\subsection{Both HBHA and LBP are Recognized by Sera from Infected Patients}

To investigate whether HBHA and LBP produced by M. intracellulare are antigenic in infected subjects, we performed ELISA using sera from 17 infected patients and six healthy controls on M. intracellulare HBHA and LBP and PPDj. The sera from the patients reacted with both HBHA and LBP purified from $M$. intracellulare (Figure 7), and the absorbance for the patients' group was significantly higher compared to that of the healthy donors. 


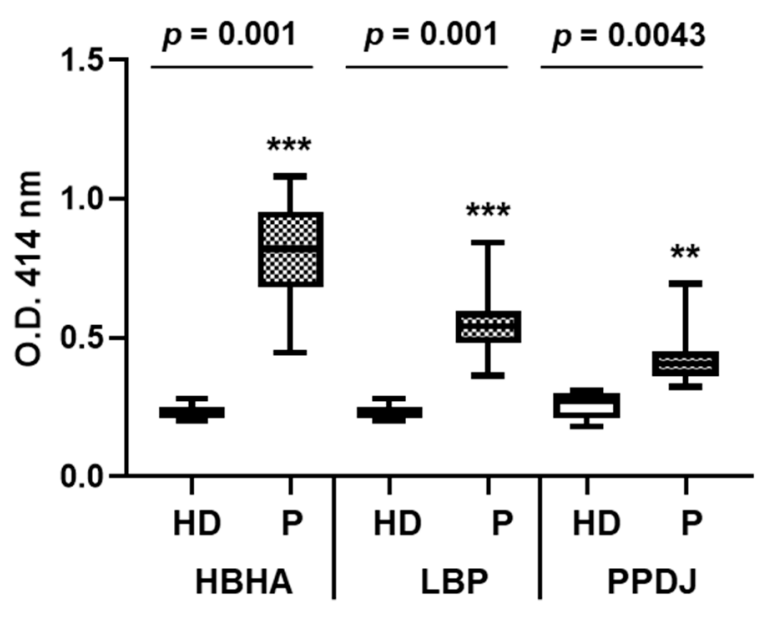

Figure 7. Human serum antibody levels to HBHA and LBP from M. intracellulare. ELISA were performed on plates coated with PPDj, HBHA or LBP purified from M. intracellulare. The panel of sera tested included 6 healthy donors (HD) and the 17 patients included in this study (P). Serum samples were realized in triplicate. Statistical analysis was performed with Tukey's multiple comparison tests. ** $p<0.005,{ }^{* * *} p=0.001$.

\section{Discussion}

One of the major outcomes of this study is the first characterization of HBHA and LBP of $M$. intracellulare. Interaction of $M$. intracellulare with airway epithelial cells can be modulated by heparin or laminin. The addition of exogenous heparin competed with the heparan sulfates present on the proteoglycan components of the cell surface, thereby reducing binding of the bacteria on epithelial cells. Conversely, adding laminin attaches to the bacteria and then binds to its cellular receptor, thereby increasing the adhesion of the bacteria to epithelial cells. Mass spectrometry analysis of heparin-Sepharose-purified M. intracellulare HBHA and LBP revealed the characteristic features of these conserved mycobacterial proteins. The affinity properties of these adhesins to sulfated heparin are comparable to their homologs described in Mycobacterium tuberculosis Complex (MTBC) and Mycobacterium leprae [19,23,41]. These adhesins possess a typical C-terminal domain consisting essentially of lysine/ alanine/proline repeats involved in the interaction with GAGs [23] (Figure 8). Pethe et al. [41], Lebrun et al. [23] and Lefrancois et al. [20] have shown a direct correlation between the number of lysine-rich repeats and the strength of heparin-binding of HBHA. Interestingly, the binding of LBP to laminin and collagen I suggests that this protein may also interact with the host basal membrane. This has been also described for the Borrelia burgdorferi protein CRASP-1 which favors adherence and tissue invasion via interaction with laminin and collagen I [42].

HBHA and LBP purified from M. intracellulare were found to be methylated, similar to the M. tuberculosis homologs [32,43]. The methylation of the functionally important domain of HBHA has been shown to be crucial for protection against proteolytic degradation [43]. In addition, the methylation of HBHA was shown to play a major role in both B and T cell antigenicity [26]. B cell responses were detected here in all patients infected with MAC strains but without differences regarding the pathology. This is not surprising given the high level of degree of similarity of the protein within the different species (Figure 8). Previous studies have shown that native, methylated HBHA from BCG can detect individuals latently infected by $M$. tuberculosis [25]. In fact, the C-terminal, methylated peptide epitopes of the M. tuberculosis HBHA are directly recognized by T-cells from latently infected subjects [44]. Furthermore, native methylated $M$. tuberculosis HBHA has been shown to provide protective immunity against $M$. tuberculosis infection in mouse models [45]. Thus, the similarities of the $M$. intracellulare HBHA with the M. tuberculosis HBHA suggest the potential usefulness of the latter for diagnosis and vaccine development against NTM infection. 


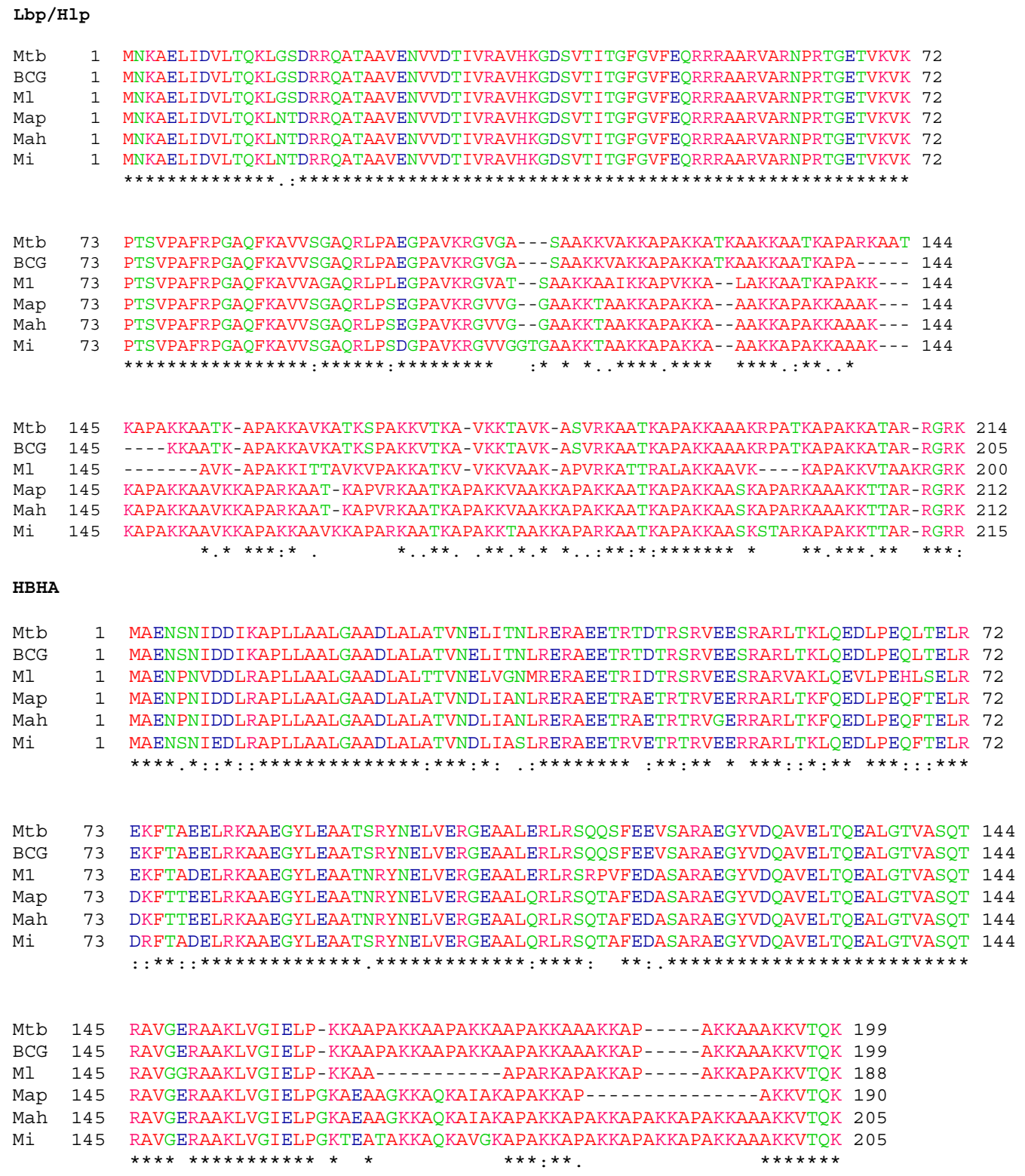

Figure 8. Sequence alignments of HBHA and LBP. Multiple sequence alignments were performed using the ClustalW program with the BLOSUM64 matrix allowing gaps $(-)$. * indicate identical residues.: indicate conserved substitutions.; indicate semi-conserved substitutions. Mtb, M. tuberculosis; BCG, M. bovis BCG; Ml, M. leprae; Map, M. avium subsp. paratuberculosis; Mah, M. avium subsp. hominissuis and Mi, M. intracellulare. Color code: Pink, Polar positively charged residues HKR; Green, Polar non-charged residues GNQSTY; Blue, Polar negatively charged residues DE and Red, other residues.

This study also revealed that HBHA and LBP do not differ among the different species belonging to the MAC complex, even though the strains were isolated from patients with different pathologies such as AIDS, bronchiectasis, leukemia and immunosuppressive pathology among others.

\section{Conclusions}

This study describes for the first time the characterization of the adhesins HBHA and LBP of $M$. intracellulare and closely NTM strains. Due to the high degree of conservation, the $h b h A$ and $l b p$ genes could be targets for the detection of these bacteria in clinical samples, and the corresponding proteins could be targets in therapeutic and vaccine purposes. 
Author Contributions: Conceptualization, F.B., P.L. and L.H.L.; methodology, F.B., P.L., L.H.L., M.B., and T.C.; software, C.C., M.B. and T.C.; formal analysis, F.B., L.H.L., M.B., T.C., and C.C.; resources, P.L., O.P. and A.P.; writing-original draft preparation, F.B., P.L. and C.L.; writing-review and editing, F.B., P.L., L.H.L. and C.L.; visualization, F.B.; supervision, F.B. and P.L. All authors have read and agreed to the published version of the manuscript.

Funding: This research received no external funding.

Acknowledgments: We are grateful to Florence B. Gilbert INRAE ISP for assistance in protein purification. We thank Ana-Paula Teixeira-Gomes (INRAE, Pôle d'Analyse et d'Imagerie des Biomolécules (PAIB), Nouzilly, France) for the MS analyses.

Conflicts of Interest: The authors declare no conflicts of interest. The funders had no role in the design of the study; in the collection, analyses, or interpretation of data; in the writing of the manuscript; or in the decision to publish the results.

\section{References}

1. Dartois, V.; Sizemore, C.; Dick, T. Editorial: NTM-The New Uber-Bugs. Front. Microbiol. 2019, 10, 1299. [CrossRef] [PubMed]

2. Johansen, M.D.; Herrmann, J.L.; Kremer, L. Non-tuberculous mycobacteria and the rise of Mycobacterium abscessus. Nat. Rev. Microbiol. 2020, 18, 392-407. [CrossRef] [PubMed]

3. Hoefsloot, W.; van Ingen, J.; Andrejak, C.; Angeby, K.; Bauriaud, R.; Bemer, P.; Beylis, N.; Boeree, M.J.; Cacho, J.; Chihota, V.; et al. The geographic diversity of nontuberculous mycobacteria isolated from pulmonary samples: An NTM-NET collaborative study. Eur. Respir. J. 2013, 42, 1604-1613. [CrossRef] [PubMed]

4. Kim, S.Y.; Shin, S.H.; Moon, S.M.; Yang, B.; Kim, H.; Kwon, O.J.; Huh, H.J.; Ki, C.S.; Lee, N.Y.; Shin, S.J.; et al. Distribution and clinical significance of Mycobacterium avium complex species isolated from respiratory specimens. Diagn. Microbiol. Infect. Dis 2017, 88, 125-137. [CrossRef]

5. Falkinham, J.O., 3rd. Epidemiology of infection by nontuberculous mycobacteria. Clin. Microbiol. Rev. 1996, 9, 177-215. [CrossRef]

6. Lacroix, A.; Piau, C.; Lanotte, P.; Carricajo, A.; Guillouzouic, A.; Peuchant, O.; Cady, A.; Dupin, C.; Fangous, M.S.; Martin, C.; et al. Emergence of Nontuberculous Mycobacterial Lymphadenitis in Children After the Discontinuation of Mandatory Bacillus Calmette and GuErin Immunization in France. Pediatr. Infect. Dis. J. 2018, 37, e257-e260. [CrossRef]

7. Johne, H.A.; Frothingham, L. Ein eigenthuemlicher fall von tuberkulose beim rind. Deutsche Zeitschrift fur tiermedicin und pathologie 1895, 21, 438-454.

8. Thorel, M.F.; Krichevsky, M.; Levy-Frebault, V.V. Numerical taxonomy of mycobactin-dependent mycobacteria, emended description of Mycobacterium avium, and description of Mycobacterium avium subsp. avium subsp. nov., Mycobacterium avium subsp. paratuberculosis subsp. nov., and Mycobacterium avium subsp. silvaticum subsp. nov. Int. J. Syst. Bacteriol. 1990, 40, 254-260. [CrossRef]

9. Mijs, W.; de Haas, P.; Rossau, R.; Van der Laan, T.; Rigouts, L.; Portaels, F.; van Soolingen, D. Molecular evidence to support a proposal to reserve the designation Mycobacterium avium subsp. avium for bird-type isolates and 'M. avium subsp. hominissuis' for the human/porcine type of M. avium. Int. J. Syst. Evol. Microbiol. 2002, 52, 1505-1518. [CrossRef]

10. Van Ingen, J.; Turenne, C.Y.; Tortoli, E.; Wallace, R.J., Jr.; Brown-Elliott, B.A. A definition of the Mycobacterium avium complex for taxonomical and clinical purposes, a review. Int. J. Syst. Evol. Microbiol. 2018, 68, 3666-3677. [CrossRef]

11. Tortoli, E.; Meehan, C.J.; Grottola, A.; Fregni Serpini, G.; Fabio, A.; Trovato, A.; Pecorari, M.; Cirillo, D.M. Genome-based taxonomic revision detects a number of synonymous taxa in the genus Mycobacterium. Infect. Genet. Evol. 2019, 75, 103983. [CrossRef] [PubMed]

12. Tortoli, E.; Rindi, L.; Garcia, M.J.; Chiaradonna, P.; Dei, R.; Garzelli, C.; Kroppenstedt, R.M.; Lari, N.; Mattei, R.; Mariottini, A.; et al. Proposal to elevate the genetic variant MAC-A, included in the Mycobacterium avium complex, to species rank as Mycobacterium chimaera sp. nov. Int. J. Syst. Evol. Microbiol. 2004, 54, 1277-1285. [CrossRef] [PubMed] 
13. Sax, H.; Bloemberg, G.; Hasse, B.; Sommerstein, R.; Kohler, P.; Achermann, Y.; Rossle, M.; Falk, V.; Kuster, S.P.; Bottger, E.C.; et al. Prolonged Outbreak of Mycobacterium chimaera Infection After Open-Chest Heart Surgery. Clin. Infect. Dis. 2015, 61, 67-75. [CrossRef] [PubMed]

14. Huh, H.J.; Kim, S.Y.; Shim, H.J.; Kim, D.H.; Yoo, I.Y.; Kang, O.K.; Ki, C.S.; Shin, S.Y.; Jhun, B.W.; Shin, S.J.; et al. GenoType NTM-DR Performance Evaluation for Identification of Mycobacterium avium Complex and Mycobacterium abscessus and Determination of Clarithromycin and Amikacin Resistance. J. Clin. Microbiol. 2019, 57. [CrossRef]

15. Cao, Y.; Wang, L.; Ma, P.; Fan, W.; Gu, B.; Ju, S. Accuracy of Matrix-Assisted Laser Desorption Ionization-Time of Flight Mass Spectrometry for Identification of Mycobacteria: A systematic review and meta-analysis. Sci. Rep. 2018, 8, 4131. [CrossRef]

16. Singh, B.; Fleury, C.; Jalalvand, F.; Riesbeck, K. Human pathogens utilize host extracellular matrix proteins laminin and collagen for adhesion and invasion of the host. FEMS Microbiol. Rev. 2012, 36, 1122-1180. [CrossRef]

17. Menozzi, F.D.; Bischoff, R.; Fort, E.; Brennan, M.J.; Locht, C. Molecular characterization of the mycobacterial heparin-binding hemagglutinin, a mycobacterial adhesin. Proc. Natl. Acad. Sci. USA 1998, 95, 12625-12630. [CrossRef]

18. Menozzi, F.D.; Rouse, J.H.; Alavi, M.; Laude-Sharp, M.; Muller, J.; Bischoff, R.; Brennan, M.J.; Locht, C. Identification of a heparin-binding hemagglutinin present in mycobacteria. J. Exp. Med. 1996, 184, 993-1001. [CrossRef]

19. Biet, F.; Angela de Melo Marques, M.; Grayon, M.; Xavier da Silveira, E.K.; Brennan, P.J.; Drobecq, H.; Raze, D.; Vidal Pessolani, M.C.; Locht, C.; Menozzi, F.D. Mycobacterium smegmatis produces an HBHA homologue which is not involved in epithelial adherence. Microbes Infect. 2007, 9, 175-182. [CrossRef]

20. Lefrancois, L.H.; Bodier, C.C.; Cochard, T.; Canepa, S.; Raze, D.; Lanotte, P.; Sevilla, I.A.; Stevenson, K.; Behr, M.A.; Locht, C.; et al. Novel feature of Mycobacterium avium subsp. paratuberculosis, highlighted by characterization of the heparin-binding hemagglutinin adhesin. J. Bacteriol. 2013, 195, 4844-4853. [CrossRef]

21. Eraghi, V.; Derakhshandeh, A.; Hosseini, A.; Haghkhah, M.; Sechi, L.A.; Motamedi Boroojeni, A. Recombinant fusion protein of Heparin-Binding Hemagglutinin Adhesin and Fibronectin Attachment Protein (rHBHA-FAP) of Mycobacterium avium subsp. paratuberculosis elicits a strong gamma interferon response in peripheral blood mononuclear cell culture. Gut Pathog. 2019, 11, 36. [CrossRef] [PubMed]

22. Sechi, L.A.; Ahmed, N.; Felis, G.E.; Dupre, I.; Cannas, S.; Fadda, G.; Bua, A.; Zanetti, S. Immunogenicity and cytoadherence of recombinant heparin binding haemagglutinin (HBHA) of Mycobacterium avium subsp. paratuberculosis: Functional promiscuity or a role in virulence? Vaccine 2006, 24, 236-243. [CrossRef] [PubMed]

23. Lebrun, P.; Raze, D.; Fritzinger, B.; Wieruszeski, J.M.; Biet, F.; Dose, A.; Carpentier, M.; Schwarzer, D.; Allain, F.; Lippens, G.; et al. Differential contribution of the repeats to heparin binding of HBHA, a major adhesin of Mycobacterium tuberculosis. PLoS ONE 2012, 7, e32421. [CrossRef] [PubMed]

24. Pethe, K.; Alonso, S.; Biet, F.; Delogu, G.; Brennan, M.J.; Locht, C.; Menozzi, F.D. The heparin-binding haemagglutinin of M. tuberculosis is required for extrapulmonary dissemination. Nature 2001, 412, 190-194. [CrossRef] [PubMed]

25. Masungi, C.; Temmerman, S.; Van Vooren, J.P.; Drowart, A.; Pethe, K.; Menozzi, F.D.; Locht, C.; Mascart, F. Differential $\mathrm{T}$ and $\mathrm{B}$ cell responses against Mycobacterium tuberculosis heparin-binding hemagglutinin adhesin in infected healthy individuals and patients with tuberculosis. J. Infect. Dis. 2002, 185, 513-520. [CrossRef] [PubMed]

26. Temmerman, S.; Pethe, K.; Parra, M.; Alonso, S.; Rouanet, C.; Pickett, T.; Drowart, A.; Debrie, A.S.; Delogu, G.; Menozzi, F.D.; et al. Methylation-dependent T cell immunity to Mycobacterium tuberculosis heparin-binding hemagglutinin. Nat. Med. 2004, 10, 935-941. [CrossRef]

27. Bitti, M.L.; Masala, S.; Capasso, F.; Rapini, N.; Piccinini, S.; Angelini, F.; Pierantozzi, A.; Lidano, R.; Pietrosanti, S.; Paccagnini, D.; et al. Mycobacterium avium subsp. paratuberculosis in an Italian cohort of type 1 diabetes pediatric patients. Clin. Dev. Immunol. 2012, 2012, 785262. [CrossRef]

28. Rosu, V.; Ahmed, N.; Paccagnini, D.; Gerlach, G.; Fadda, G.; Hasnain, S.E.; Zanetti, S.; Sechi, L.A. Specific immunoassays confirm association of Mycobacterium avium Subsp. paratuberculosis with type-1 but not type-2 diabetes mellitus. PLoS ONE 2009, 4, e4386. [CrossRef] [PubMed] 
29. De Melo Marques, M.A.; Mahapatra, S.; Nandan, D.; Dick, T.; Sarno, E.N.; Brennan, P.J.; Vidal Pessolani, M.C. Bacterial and host-derived cationic proteins bind alpha2-laminins and enhance Mycobacterium leprae attachment to human Schwann cells. Microbes Infect. 2000, 2, 1407-1417. [CrossRef]

30. Shimoji, Y.; Ng, V.; Matsumura, K.; Fischetti, V.A.; Rambukkana, A. A 21-kDa surface protein of Mycobacterium leprae binds peripheral nerve laminin-2 and mediates Schwann cell invasion. Proc. Natl. Acad. Sci. USA 1999, 96, 9857-9862. [CrossRef]

31. Silva, C.A.; Danelishvili, L.; McNamara, M.; Berredo-Pinho, M.; Bildfell, R.; Biet, F.; Rodrigues, L.S.; Oliveira, A.V.; Bermudez, L.E.; Pessolani, M.C. Interaction of Mycobacterium leprae with human airway epithelial cells: Adherence, entry, survival, and identification of potential adhesins by surface proteome analysis. Infect. Immun. 2013, 81, 2645-2659. [CrossRef] [PubMed]

32. Lefrancois, L.H.; Pujol, C.; Bodier, C.C.; Teixeira-Gomez, A.P.; Drobecq, H.; Rosso, M.L.; Raze, D.; Dias, A.A.; Hugot, J.P.; Chacon, O.; et al. Characterization of the Mycobacterium avium subsp. paratuberculosis laminin-binding/histone-like protein ( $\mathrm{Lbp} / \mathrm{Hlp})$ which reacts with sera from patients with Crohn's disease. Microbes Infect. 2011, 13, 585-594. [CrossRef] [PubMed]

33. Soares de Lima, C.; Zulianello, L.; Marques, M.A.; Kim, H.; Portugal, M.I.; Antunes, S.L.; Menozzi, F.D.; Ottenhoff, T.H.; Brennan, P.J.; Pessolani, M.C. Mapping the laminin-binding and adhesive domain of the cell surface-associated Hlp/LBP protein from Mycobacterium leprae. Microbes Infect. 2005, 7, 1097-1109. [CrossRef] [PubMed]

34. Telenti, A.; Marchesi, F.; Balz, M.; Bally, F.; Bottger, E.C.; Bodmer, T. Rapid identification of mycobacteria to the species level by polymerase chain reaction and restriction enzyme analysis. J. Clin. Microbiol. 1993, 31, 175-178. [CrossRef] [PubMed]

35. Dauchy, F.A.; Degrange, S.; Charron, A.; Dupon, M.; Xin, Y.; Bebear, C.; Maugein, J. Variable-number tandem-repeat markers for typing Mycobacterium intracellulare strains isolated in humans. BMC Microbiol. 2010, 10, 93. [CrossRef]

36. Humphreys, I.R.; Stewart, G.R.; Turner, D.J.; Patel, J.; Karamanou, D.; Snelgrove, R.J.; Young, D.B. A role for dendritic cells in the dissemination of mycobacterial infection. Microbes Infect. 2006, 8, 1339-1346. [CrossRef]

37. Lefrancois, L.H.; Bodier, C.C.; Lecher, S.; Gilbert, F.B.; Cochard, T.; Harichaux, G.; Labas, V.; Teixeira-Gomes, A.P.; Raze, D.; Locht, C.; et al. Purification of native HBHA from Mycobacterium avium subsp. paratuberculosis. BMC Res. Notes 2013, 6, 55. [CrossRef]

38. Bourin, M.; Gautron, J.; Berges, M.; Attucci, S.; Le Blay, G.; Labas, V.; Nys, Y.; Rehault-Godbert, S. Antimicrobial potential of egg yolk ovoinhibitor, a multidomain Kazal-like inhibitor of chicken egg. J. Agric. Food Chem. 2011, 59, 12368-12374. [CrossRef]

39. Pethe, K.; Puech, V.; Daffe, M.; Josenhans, C.; Drobecq, H.; Locht, C.; Menozzi, F.D. Mycobacterium smegmatis laminin-binding glycoprotein shares epitopes with Mycobacterium tuberculosis heparin-binding haemagglutinin. Mol. Microbiol. 2001, 39, 89-99. [CrossRef]

40. Rouse, D.A.; Morris, S.L.; Karpas, A.B.; Mackall, J.C.; Probst, P.G.; Chaparas, S.D. Immunological characterization of recombinant antigens isolated from a Mycobacterium avium lambda gt11 expression library by using monoclonal antibody probes. Infect. Immun. 1991, 59, 2595-2600. [CrossRef]

41. Pethe, K.; Aumercier, M.; Fort, E.; Gatot, C.; Locht, C.; Menozzi, F.D. Characterization of the heparin-binding site of the mycobacterial heparin-binding hemagglutinin adhesin. J. Biol. Chem. 2000, 275, 14273-14280. [CrossRef] [PubMed]

42. Hallstrom, T.; Haupt, K.; Kraiczy, P.; Hortschansky, P.; Wallich, R.; Skerka, C.; Zipfel, P.F. Complement regulator-acquiring surface protein 1 of Borrelia burgdorferi binds to human bone morphogenic protein 2, several extracellular matrix proteins, and plasminogen. J. Infect. Dis. 2010, 202, 490-498. [CrossRef] [PubMed]

43. Pethe, K.; Bifani, P.; Drobecq, H.; Sergheraert, C.; Debrie, A.S.; Locht, C.; Menozzi, F.D. Mycobacterial heparin-binding hemagglutinin and laminin-binding protein share antigenic methyllysines that confer resistance to proteolysis. Proc. Natl. Acad. Sci. USA 2002, 99, 10759-10764. [CrossRef] [PubMed] 
44. Corbiere, V.; Segers, J.; Desmet, R.; Lecher, S.; Loyens, M.; Petit, E.; Melnyk, O.; Locht, C.; Mascart, F. Natural T Cell Epitope Containing Methyl Lysines on Mycobacterial Heparin-Binding Hemagglutinin. J. Immunol. 2020, 204, 1715-1723. [CrossRef]

45. Parra, M.; Pickett, T.; Delogu, G.; Dheenadhayalan, V.; Debrie, A.S.; Locht, C.; Brennan, M.J. The mycobacterial heparin-binding hemagglutinin is a protective antigen in the mouse aerosol challenge model of tuberculosis. Infect. Immun. 2004, 72, 6799-6805. [CrossRef]

(C) 2020 by the authors. Licensee MDPI, Basel, Switzerland. This article is an open access article distributed under the terms and conditions of the Creative Commons Attribution (CC BY) license (http://creativecommons.org/licenses/by/4.0/). 